Directory of British Insecticides, Fungicides and Weedkillers

THE Association of British Insecticide Manufacturers has recently published the third edition (1956) of its "Directory" of British insecticides, fungicides and weedkillers (pp. 128; from the Association, London, 1956). In addition to a directory of member firms of the Association, the publication provides information on the chemicals available for the control of insects, fungi and weeds, and where they may be obtained. Proprietary and trade names are also given, with an indication of the use of each proprietary product. Information is also given on where to obtain accessory materials such as wetters, spreaders and stickers and the machines for applying the chemicals. 'T'he Directory should prove most useful to all those intercsted in the supply and use of chemicals for pest control. It is fully indexed.

\section{Library of the University of Leeds: Report for} 1954-55

THE annual report of the librarian of the University of Leeds for the session 1954-55 (pp. 12; from the Brotherton Library, Leeds) records holdings on June 30,1955 , of 389,118 volumes and 163,866 pamphlets. Of these, 279,625 volumes and 110,988 pamphlets are in the Brotherton Library, the corresponding figures for the Medical Library being 28,209 and 3,645, respectively ; for the Agricultural Library, 9,457 and 25,980 ; and for the Textile Library, 5,225 and 900. Accessions for the year totalled 9,859 volumes, 2,355 pamphlets and 25,762 periodical parts, a decrease of 7 per cent. Loans to readers totalled 94,531, an increase of 4 per cent, and inter-library loans totalled 4,218 , the books borrowed increasing by 22 per cent to 1,510 and those lent by 2 per cent to 2,708 . Detailed consideration was given during the year to regulations for the consultation and loan of theses, and there was no difficulty in accepting the general desirability of making available the work contained in theses of the University. Subject to the desire to protect the author and obviate premature publication prejudicial both to the author himself and the department concerned, every effort will be made to facilitate the proper use of thesis material by qualified readers both in the University and outside it. The Council of the University has also generally approved the proposal that graduate members of the library staff should, in suitable circumstances, be given periods of up to three months of leave for research. Staff changes have been largely responsible for a 34 per cent fall in the cataloguing output, but the insistent demands of the reading room and the need of assistance in the sectional libraries have also contributed to this.

\section{Oversea Service Division, Colonial Office}

The following appointments have recently been made in the Oversea Service Division, Colonial Office: W. H. Ldwards (agricultural officor, Uganda), assistant director of agriculture (field), Uganda; A. M. M. Rees (agricultural econornist, Northern Rhodesia), agricultural economist, Jamaica; 'T. A. A. 'Talbot (assistant agricultural officer, Kenya), agricultural officer, Kenya; J. D. Yelf (agricultural officer, Northern Rhodesia), senior agricultural officer, Fiji ; P. F. Burgess (assistant conservator of forests, Federation of Malaya), senior assistant conservator of forests, North Borneo; F. G. Harper (conservator of forests, Gold (Coast), deputy chief conservator of forests, Gold Coast ; Dr. J. R. Audy (medical officer, Institute for Medical Research, Kuala Lumpur, Federation of Malaya), specialist (grade B), senior virus research officer (superscale $\mathrm{H}$ ), Federation of Malaya ; E. F. Duck (government pathologist, Hong Kong), pathologist, General Hospital, Bahamas; M. P. Hutchinson (research epidemiologist, West African Institute for Trypanosomiasis Research), deputy director, West African Institute for Trypanosomiasis Research); Miss V. Suter (scientific officer, Colonial Microbiological Research Unit, 'Trinidad), senior scientific officer, Colonial Microbiological Research Unit, Trinidad; P. T. Walker (scientific officer, Colonial Insecticides Research Unit, Tanganyika), senior scientific officer, Colonial Insecticides Research Unit, Tanganyika; A. E. Dorman (provincial veterinary officer, Kenya), assistant director of veterinary services, Kenya; K. J. R. Maclennan (senior veterinary officer, Norihern Region, Nigeria), principal veterinary officer, Northern Region, Nigeria; W. Plowright (veterinary research officer, Federation of Nigeria), veterinary research officer (pathologist), East African Veterinary Research Organization, East Africa High Commission; A. J. Bearman (principal, School of Pharmacy, Federation of Nigeria), chief pharmacist, Federation of Nigeria ; E. Cundiff, agricultural officer, British Guiana; C. L. M. van Eynatten, seientific officer, plant breeder, Maize Rust Research Unit, Federation of Nigeria ; K. Paijmans, assistant conservator of forests, Gold Coast ; M. J. Fleuty, geologist, Uganda; J. D. Arneaud, pathologist (grade A), Trinidad; A. T. Brough, statistician, East Africa High Commission ; G. D. Phillips, veterinary research officer, East Afjica High Commission.

\section{Announcements}

DR. T. K. Walker, reader in fermentation processes in the Faculty of Technology, University of Manchester, has been given the status of professor, with the titlo of professor of industrial biochemistry, in the University.

IN the article entitled "Tube Investments Research Laboratories" in Nature of July 14, p. 60, it should have been stated that the cobalt irradiation equipment was designed and built by Nuclear Engineering, Ltd., of Grcenwich Metal Works, London, S.E.7.

Tubercle, the journal of the British Tuberculosis Association, has, since the beginning of this year, appeared two-monthly in an enlarged size, with an improved format. In addition to tuberculosis, the journal deals with respiratory disease in general and related infections, for example, leprosy ; laboratory as well as clinical and epidemiological aspects are included. Dr. J. R. Bignall has recently been made editor and a new Editorial Committee appointed.

IN 1955, the Muséum d'Histoire Naturelle, Paris, set up an exhibition to direct attention to the importance of safeguarding natural resources and to illustrate the damage done to animal and plant life and to the soil itself. The nucleus of this exhibition is now being sent to a number of different countries. In Britain, under arrangements made by the Society of the Men of the 'Trees, it is being shown in the Senate House of the University of Cambridge during July 18-31; and it is hoped that it will be shown afterwards in London.

Erratum. In the communication entitled "Origin of the Common Wild Oat, Avena fatua L.", by D.J. Griffiths and T. D. Johnston (Nature, July 14, p. 99), Fig. 1 has been inadvertently printed upside-down. 